\title{
PENGARUH KEYAKINAN DIRI DAN PENGETAHUAN AWAL TERHADAP MINAT BELAJAR MATERI AKUNTANSI KELAS XII SMA NEGERI DI KOTA MOJOKERTO
}

\begin{abstract}
Anis Istibsyaroh
ABSTRACT

This correlational study investigates the effect of 1) self confidence on the student's learning interest in Accounting, 2) prior knowledge on the students' learning interest in Accounting, and 3) both self confidence and prior knowledge on the students'learning interest in Accounting. Data were analyzed by using regression analysis, single tail t-test, and simultaneous F test. 345 of grade XII students of three senior high schools in Mojokerto (SMA Negeri 1, SMA Negeri 2 dan SMA Negeri 3) are the population of the study and 177 of them were taken as the sampled subjects using proportional random sampling technique. The finding shows that the operational t coefficient for self confidence is 9.708 (d.f.: 0.000) and the operational t coefficient for prior knowledge is 2.818 (d.f.: 0.005). In addition, the simultaneous $F$ analysis yields in 58.047 (d.f.: 0.000). In conclusion, the higher the self confidence and prior knowledge the students have, the better their learning interest in Accounting will be. Similarly, these two variables simultaneously influence the learning interest in Accounting.
\end{abstract}

Keywords: Self confidence, Prior Knowledge, Learning Interest in Accounting.

\section{PENDAHULUAN}

$\mathrm{P}$ ada saat ini sekolah telah menerapkan Kurikulum Tingkat Satuan Pendidikan (KTSP) yang menekankan keterlibatan aktif antara guru dan siswa dalam proses belajar mengajar. Dalam KTSP menuntut adanya partisipasi aktif dari seluruh siswa. Jadi kegiatan belajar terpusat pada siswa, guru hanya sebagai motivator dan fasilitator agar suasana kelas menjadi lebih hidup.

Keberhasilan siswa dimana sangat ditentukan oleh minat dalam menerima materi yang disampaikan guru dalam proses belajar mengajar. Pada mata pelajaran ekonomi materi kuntansi, ditemukan fenomena kurangnya minat belajar siswa pada materi akuntansi di kelas XII SMA Negeri di kota Mojokerto terbukti masih banyak nilai ulangan harian yang dibawah Kriteria Ketuntasan Minimal yang disebabkan oleh rendahnya keyakinan diri siswa untuk bisa karena dari wawancara sebagian siswa mengatakan bahwa akuntansi merupakan materi yang sangat membutuhkan ketelitian dan kurangnya pemahaman materi akuntansi sebagai pengetahuan awal mereka karena di kelas XII SMA Negeri di kota Mojokerto masih ditemukan adanya kesenjangan nilai ulangan harian yang jauh

antara nilai yang rendah dengan nilai yang di atas KKM, padahal semua siswa SMA Negeri di kota Mojokerto telah menerima materi akuntansi perusahaan jasa yang telah diterima di kelas XI sebagai dasar pengetahuan awal untuk mempelajari akuntansi pe*) SMA Negeri 2 Kota Mojokerto 
rusahaan dagang di kelas XII. Dari fenomena di atas penulis mengambil judul Pengaruh Keyakinan Diri dan Pengetahuan Awal Terhadap Minat Belajar Materi Akuntansi Kelas XII SMA di Kota Mojokerto.

Menurut Slameto (2010:180) minat adalah suatu rasa lebih suka dan rasa keterikatan pada suatu hal atau aktivitas tanpa ada yang menyuruh. Minat pada dasarnya adalah penerimaan akan suatu hubungan antara diri sendiri dengan sesuatu diluar diri. Semakin kuat atau dekat hubungan tersebut, semakin besar minat. Berdasarkan latar belakang diatas maka penulis mengambil judul Pengaruh Keyakinan Diri dan Pengetahuan Awal Terhadap Minat Belajar Materi Akuntansi Kelas XII SMA di Kota Mojokerto.

Menurut Santrock (2009:324) keyakinan diri (self efficacy) adalah keyakinan bahwa seseorang dapat menguasai situasi dan menciptakan hasil yang positif. Menurut Amalia (2008:8) keyakinan diri (self-efficacy) dibangun dalam hubungan antara sifat-sifat pribadi, pola prilaku dan faktor lingkungan. Dari pengertian tersebut dapat disimpulkan bahwa keyakinan diri akan mempengaruhi pola prilaku diri dengan sesuatu diluar diri.

Menurut Nur (2011:10) pengetahuan awal adalah kumpulan dari pengetahuan dan pengalaman individu yang diperoleh sepanjang perjalanan hidup mereka, dan apa yang ia bawa kepada suatu pengalaman belajar baru. Sedangkan dalam penelitian ini pengetahuan awal yang dimaksud adalah pemahaman kompetensi dasar akuntansi yang telah diberikan di kelas XI. Kompetensi dasar menurut kurikulum 2004 tentang standar kompetensi mata pelajaran akuntansi SMA dan MA (2004:10) adalah kemampuan minimal dalam mata pelajaran yang harus dimiliki yang direfleksikan dalam kebiasaan berpikir dan bertindak.

Kebaruan penelitian dapat dikatakan sebagai salah satu kriteria yang harus dipenuhi atau sesuatu yang harus mampu ditunjukkan oleh sebuah penelitian agar penelitian itu menghasilkan temuan yang bernilai dan bermanfaat. Oleh karena itu sebuah penelitian haruslah memiliki fondasi yang berupa fenomena yang krusial sehingga kebaruan yang dihasilkan signifikan. Kebaruan hasil penelitian ini dari penelitian terdahulu merupakan penguatan dan pengembangan. Penelitian yang akan dilakukan sifatnya adalah melengakapi temuan penelitian terdahulu dan menguji kembali serta memberikan penguatan tentang variabel keyakinan diri (self efficacy) pengetahuan awal dan minat belajar akuntansi.

Dengan masih kurangnya minat belajar pada mata pelajaran akuntansi pada kelas XII IPS tingkat SMA Negeri di kota Mojokerto, maka solusi dari permasalahan tersebut adalah dengan keyakinan diri (self efficacy) yang tinggi dan berbekal pengetahuan awal tentang akuntansi yang telah dipelajari di kelas akan tumbuh minat belajar pada mata pelajaran ekonomi materi akuntansi di kelas XII.

Penelitian terdahulu yang dilakukan oleh Rika Indah Amalia tahun 2008 dengan judul Pengaruh Self Efficacy Beliefs terhadap Prestasi Akademik Siswa SMA Kelas XI Jurusan IPS menyebutkan tidak terdapat pengaruh self efficacy beliefs terhadap prestasi akademik.

Penelitian yang dilakukan oleh Elsye Tandelilin tahun 2005 yang berjudul Kompetensi Dosen, Keyakinan Diri (Self Efficacy) dan Motivasi Mahasiswa: Pengaruhnya terhadap Prestasi Mahasiswa (Student Achievement) Fakultas Ekonomi Universitas Surabaya menyebutkan bahwa hasil penelitian menunjukkan bahwa kompetensi dosen berpengaruh positif dan signifikan terhadap siswa diri efikasi. Keyakinan diri (self-efficacy) mahasiswa berhubungan positif dengan prestasi siswa. Secara tidak langsung kompetensi dosen memiliki dampak positif dan signifikan terhadap prestasi siswa melalui keyakinan diri (self 
efficacy) siswa.

Penelitian yang dilakukan oleh Ross A. Thomson dan Byron L. Zamboanga yang berjudul Academic Aptitude and Prior Knowledge as Predictors of Student Achievement in Introduction to Psychology hasil penelitiannya menunjukkan di luar kemampuan umum pengetahuan sebelumnya memfasilitasi belajar siswa dalam pengantar psikologi.

Penelitian yang dilakukan oleh Harry B Santoso, Tunggul Fardiaz dan Zainal A Hasibuan yang berjudul Implementasi Fitur Perekomendasian Bahan Ajar Berdasarkan Prior Knowledge pada Student Centered E-Learning Environment hasil penelitiannya menunjukkan bahwa mahasiswa mendapatkan bahan ajar sesuai dengan prior knowledge yang dimiliki seperti level dasar (basic), menengah (medium), dan tinggi (advance) sebagai pengetahuan awal untuk mengkonstruksi pengetahuan baru.

Perbedaan antara penelitian yang peneliti coba susun dengan empat penelitian sebelumnya adalah terletak pada variable terikat. Pada penelitian sebelumnya keyakinan diri (self efficacy) berpengaruh pada prestasi belajar maka pada penelitian kali ini, peneliti mencoba mengganti variabel terikat dengan minat belajar akuntansi dan mencoba menambah variabel bebas dengan variabel pengetahuan awal. Temuan-temuan ini menarik untuk diteliti kembali khususnya tingkat SMA Negeri di Mojokerto dengan segala fenomena dan kondisi yang ada.

Dari judul tersebut dapat ditarik rumusan masalah sebagai berikut: 1). Adakah pengaruh keyakinan diri (self efficacy) siswa terhadap minat belajar materi akuntansi di kelas XII? 2). Adakah pengaruh pengetahuan awal terhadap minat belajar materi akuntansi di kelas XII? 3). Adakah pengaruh keyakinan diri (self efficacy) siswa dan pengetahuan awal terhadap minat belajar materi akuntansi di kelas XII?

Penelitian ini bertujuan untuk mengetahui: 1). Menganalisis pengaruh keyakinan diri (self efficacy) siswa terhadap minat belajar materi akuntansi di kelas XII. 2). Menganalisis pengaruh pengetahuan awal terhadap minat belajar materi akuntansi di kelas XII. 3). Menganalisis pengaruh keyakinan diri (self efficacy) siswa dan pengetahuan awal terhadap minat belajar materi akuntansi di kelas XII.

Keyakinan diri (self efficacy) adalah sebuah konsep yang dirumuskan oleh Albert Bandura tahun 1997, guru besar psikologi di Standford University. Keyakinan diri (self efficacy) didasarkan pada kerangka teori besar yaitu teori social cognitive. Teori social cognitive ini berfokus pada cara-cara dimana seseorang belajar dari hasil pengamatan.

Menurut Santrock (2009:324) keyakinan diri (self efficacy) adalah keyakinan bahwa seseorang dapat menguasai situasi dan menciptakan hasil yang positif. Sedangkan menurut Pajares (dalam Amalia, 2008:7) keyakinan diri (self efficacy beliefs) adalah penilaian seseorang terhadap kemampuan diri untuk mengorganisasikan dan melaksanakan langkahlangkah yang terarah untuk mencapai suatu tujuan. Untuk lebih memahami pengertian keyakinan diri (self efficacy) menurut Bandura (dalam Setiadi, 2007:3) mendefinisikan bahwa self-efficacy adalah "refers to beliefs in one's capabilities to organize and execute the courses of action required to produce given attainment" yang artinya keyakinan diri (self efficacy) mengacu pada keyakinan seseorang terhadap kemampuan yang dimilikinya untuk mengorganisasikan dan melaksanakan serangkaian tindakan yang harus dilakukan untuk menghasilkan tujuan yang telah ditetapkan.

Keyakinan diri (self efficacy) bukan merupakan keterampilan melainkan lebih kepada kepercayaan seseorang akan keahlian yang dapat dilakukannya dalam situasi tertentu. Keyakinan diri (self efficacy) tidak hanya sebagai prediksi tentang perilaku seperti 
ungkapan "saya akan" tetapi lebih kepada ungkapan "saya dapat melakukan". Selanjutnya keyakinan diri (self efficacy) didefinisikan dan diukur bukan sebagai sifat melainkan sebagai keyakinan tentang kemampuan untuk mengkoordinasikan keterampilan dan kemampuan untuk mencapai tujuan yang diinginkan dalam domain dan keadaan tertentu.

Dari ketiga definisi ahli di atas, maka jelas yang dimaksud dengan keyakinan diri (self-efficacy) merupakan keyakinan yang dimiliki oleh seseorang akan suatu kemampuan yang dimilikinya dalam mengorganisasikan serangkaian tindakan yang akan digunakan dalam mencapai tujuannya.

Menurut Nur (2011:10) pengetahuan awal (prior knowledge) adalah kumpulan dari pengetahuan dan pengalaman individu yang diperoleh dari sepanjang perjalanan hidup mereka, dan apa yang ia bawa kepada suatu pengalaman belajar baru. Suatu pengetahuan awal siswa menentukan kemungkinan-kemungkinan pembelajaran baru. Pengetahuan baru spesifik fakta, konsep, dan ketrampilan tidak dapat dipelajari sampai suatu dasar berupa pengetahuan terkait telah dipelajari.

Jadi pengetahuan awal (prior knowledge) adalah kumpulan dari pengetahuan dan pengalaman individu yang diperoleh sepanjang perjalanan hidup mereka, dan apa yang akan ia bawa ke $\neg$ pada suatu pengalaman belajar yang baru. Apa yang telah diketahui oleh individu sedikit banyak mempengaruhi apa yang mereka pelajari. Tam $\neg$ paknya, seseorang belajar dengan menghubung $\neg$ kan ide-ide baru dengan ide-ide lama.

Menurut Slameto (2010:180) mengemukakan bahwa minat adalah suatu rasa lebih suka dan rasa keterikatan pada suatu hal atau aktivitas, tanpa ada yang menyuruh. Suatu minat dapat diekspresikan melalui suatu pernyataan yang menunjukkan bahwa siswa lebih menyukai sesuatu dari pada lainnya atau melalui partisipasi/keikutsertaannya dalam suatu aktivitas. Siswa yang memiliki minat terhadap subyek tertentu cenderung untuk memberikan perhatian yang lebih besar terhadap subyek tersebut. Dari pengertian diatas dapat disimpulkan bahwa minat adalah kecenderungan seseorang terhadap obyek atau sesuatu kegiatan yang digemari yang disertai dengan perasaan senang, adanya perhatian dan keaktifan berbuat. Minat mengandung kognisi (mengenal), emosi (perasaan) dan konasi (kehendak). Oleh karena itu minat dianggap sebagai respon yang sadar, sebab jika tidak demikian, minat tidak mempunyai arti apa-apa. Unsur kognisi maksudnya adalah minat itu didahului oleh pengetahuan dan informasi mengenai obyek yang dituju oleh minat tersebut, ada unsure emosi karena dalam partisipasi atau pengalaman itu disertai oleh perasaan tertentu, seperti rasa senang, sedangkan unsure konasi merupakan kelanjutan dari unsure kognisi. Dari ketiga unsur inilah yang diwujudkan dalam bentuk kemauan dan hasrat untuk melakukan kegiatan, termasuk kegiatan yang ada disekolah seperti belajar. Sedangkan yang penulis maksudkan dengan minat belajar akuntansi adalah kemampuan belajar akuntansi yang dimiliki siswa untuk mencapai hasil belajar yang optimal yang dapat ditunjukkan dengan kegiatan belajar.

Secara teori keyakinan diri dapat mempengaruhi minat. Menurut Bandura (2012:7) orang dengan keyakinan yang kuat akan memiliki kemampuan:

1. Menganggap tugas yang sulit sebagai tantangan yang harus dikuasai (bukan ancaman yang harus dihindari)

2. Menumbuhkan ketertarikan.

3. Menetapkan tujuan yang menantang dan menjaga komitmen terhadap tujuan tersebut.

4. Memiliki usaha yang tinggi.

Sehingga mereka berfikir secara strategi, mengaitkan kegagalan dengan usaha yang cu- 
kup dan cepat bangkit setelah mengalami kegagalan. Dari teori di atas dapat disimpulkan bahwa keyakinan diri yang kuat dapat mempengaruhi minat seseorang untuk melakukan tindakan dengan rasa senang.

Secara teori pengetahuan awal adapat mempengaruhi minat, seperti yang dikatakan Renninger (dalam Schunk, 2012:321) minat memberikan nilai yang tinggi untuk sebuah aktivitas, jika individu hanya memiliki sedikit pengetahuan tentang sebuah aktivitas atau topik, sulit baginya menilai minatnya terhadap aktivitas atau topik tersebut. Individu biasanya memiliki lebih banyak pengetahuan tentang aktivitas yang sangat diminatinya dan yang akan ia berikan nilai tinggi. Oleh karena itu jika individu memberikan nilai tinggi untuk sebuah aktivitas, namun berlevel pengetahuan rendah tentang aktivitas tersebut maka bukanlah minat melainkan ketertarikkan.

Penelitian ini bertujuan untuk mendapatkan bukti-bukti empiris yang berkaitan dengan pengaruh antara variabel keyakinan diri (self efficacy) dan pengetahuan awal berupa pemahaman kompetensi dasar akuntansi kelas XI terhadap minat belajar mata pelajaran ekonomi materi akuntansi di kelas XII.

Berdasarkan kajian pustaka di atas, peneliti merumuskan hipotesis sebagai berikut:

1. Diduga keyakinan diri berpengaruh signifikan terhadap minat belajar materi akuntansi.

2. Diduga pengetahuan awal berpengaruh signifikan terhadap minat belajar materi akuntansi.

3. Diduga keyakinan diri dan pengetahuan awal berpengaruh signifikan terhadap minat belajar materi akuntansi.

\section{METODE PENELITIAN}

Pendekatan penelitian yang digunakan dalam penelitian ini adalah penelitian kuantitatif. Hariwijaya (2008:56) menjelaskan bahwa "metode kuantitatif digunakan pada penelitian dimana data dapat diidentifikasi dengan mudah". Hajar (1999:30) mengatakan "hasil penelitian kuantitatif disajikan dalam bentuk deskripsi dengan menggunakan angka-angka statistik". Jenis penelitian yang digunakan adalah penelitian tingkat eksplanasi (level of explanation). Jenis penelitian tingkat eksplanasi dalam penelitian ini digunakan untuk menggambarkan bagaimana keyakinan diri (self efficacy) dan pengetahuan awal (prior knowledge) mempengaruhi minat siswa belajar akuntansi kelas XII IPS tingkat
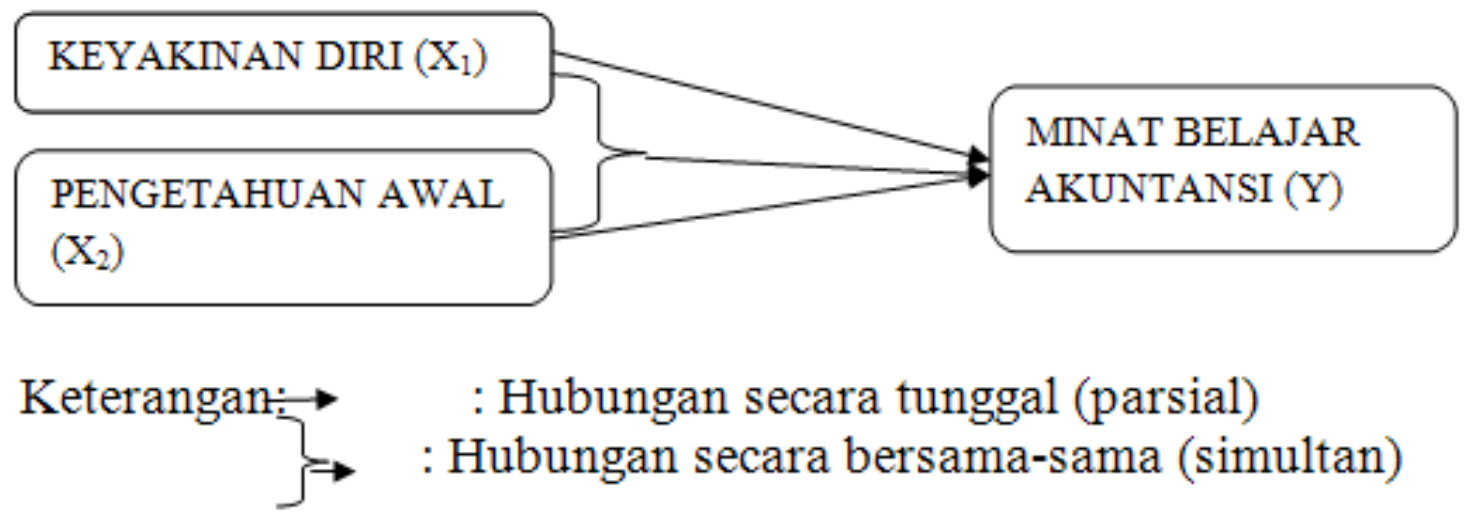

Gambar 1. Model Hubungan Variabel X1 dan X2 dengan Y 
SMA Negeri di Kota Mojokerto. Yang digunakan adalah penelitian tingkat eksplanasi asosiatif bentuk kausal yang artinya jika siswa memiliki keyakinan diri (self efficacy) yang tinggi dan kemampuan dasar akuntansi yang baik maka minat belajar terhadap mata pelajaran akuntansi dikelas XII IPS juga meningkat.

Dalam penelitian ini ada 2 variabel bebas yaitu variabel keyakinan diri (X1) dan variable pengetahuan awal (X2), sedangkan variabel terikatnya adalah minat belajar akuntansi. Rancangan penelitian disajikan pada gambar 1.

Populasi dalam penelitian ini adalah semua siswa kelas XII IPS SMA Negeri yang berada di kota Mojokerto yang meliputi SMA Negeri 1, SMA Negeri 2 dan SMA Negeri 3 yang berjumlah 345 siswa. Menurut Isaac dan Michael (dalam Sugiono, 2010:71) jumlah sampel dari populasi 345 untuk taraf kesalahan 5\% adalah 177 siswa. Untuk memenuhi keseluruhan jumlah sampel yang diinginkan sebanyak 177 siswa, maka tiap sekolah diambil sampel dengan cara jumlah populasi tiap sekolah dibagi jumlah populasi siswa keseluruhan sekolah kemudian dikali jumlah anggota sampel total sehingga dihasilkan jumlah sampel yang diambil pada tiap sekolah sebagai berikut: 1). SMA Negeri1Kota Mojokerto jumlah populasi sebanyak 162 siswa dibagi dengan jumlah populasi seluruhnya 345 dikalikan dengan sampel yang digunakan yaitu sebesar 177 hasilnya sebesar 83 siswa, 2). SMA Negeri 2 Kota Mojokerto jumlah populasi sebanyak 87 siswa dibagi dengan jumlah populasi seluruhnya 345 dikalikan dengan sampel yang digunakan yaitu sebesar 177 hasilnya sebesar 45 siswa, 3). SMA Negeri 3 Kota Mojokerto jumlah populasi sebanyak 96 siswa dibagi dengan jumlah populasi seluruhnya 345 dikalikan dengan sampel yang digunakan yaitu sebesar 177 hasilnya sebesar 49 siswa. Jasi jumlah sampel yang digunakan dalam penelitian ini sebanya 177 siswa terdiri dari 83 siswa SMA Negeri 1, siswa terdiri dari 45 siswa SMA Negeri 2, siswa terdiri dari 49 siswa SMA Negeri 3.

Teknik pengumpulan data antara lain: dokumentasi untuk variabel pengetahuan awal dengan menggunakan rata-rata nilai ulangan harian serta angket untuk variabel keyakinan diri dan minat belajar. Berikut kisi-kisi kuesioner keyakinan diri dan minat belajar:

1. Indikator variabel keyakinan diri kelas XII IPS terdiri dari:

a. Magnitude:

1). Siswa yakin mampu memahami materi yang sulit.

2). Siswa yakin mampu mengatasi hambatan dalam tingkat kesulitan tugas yang dihadapinya.

3). Siswa berminat pada mata pelajaran akuntansi.

b. Generality:

1). Siswa yakin memiliki kemamuan dalam berbagai macam tugas.

c. Strength:

1). Siswa yakin pengalaman buruk tidak akan menghalangi pencapaian keberhasilan.

2). Siswa yakin mampu mengerjakan tugas dalam berbagai situasi dan kondisi.

3). Siswa yakin mampu menyelesaikan tugas dengan tuntas.

2. Indikator variabel minat belajar materi akuntansi kelas XII IPS terdiri dari:

- Mempunyai kecenderungan yang tetap untuk untuk memperhatikan dan mengenang sesuatu yang dipelajari secara terus menerus.

- Ada rasa suka dan senang pada sesuatu yang diminati.

- Memperoleh suatu kebanggaan dan kepuasan pada sesuatu yang diminati. Ada rasa 
keterikatan pada sesuatu aktivitas-aktivitas yang diminati.

- Lebih menyukai suatu hal yang menjadi minatnya daripada yang lainnya.

- Dimanifestasikan melalui partisipasi pada aktivitas dan kegiatan.

Teknik analisis data yang digunakan adalah analisis regresi berganda dalam penelitian ini digunakan untuk mengetahui besarnya pengaruh keyakinan diri dan pengetahuan awal terhadap minat belajar akuntansi. Adapun rumus regresi berganda adalah sebagai berikut:

$$
\mathrm{Y}=\mathrm{a}+\mathrm{b} 1 \mathrm{X} 1+\mathrm{b} 2 \mathrm{X} 2
$$

Keterangan:

$\mathrm{Y} \quad=$ minat belajar akuntansi

a $\quad=$ intersep atau konstan

$\mathrm{b} 1, \mathrm{~b} 2=$ koefisien regresi dari variable bebas $(\mathrm{X} 1, \mathrm{X} 2)$

$\mathrm{X} 1=$ variabel bebas 1 yaitu keyakinan diri

$\mathrm{X} 2=$ variabel bebas 2 yaitu pengetahuan awal

Sedangkan teknik pembuktian hipotesis menggunakan: uji F untuk menguji variabel keyakinan diri dan pengetahuan awal secara simultan terhadap minat belajar materi akuntansi, uji t untuk menguji variabel bebas secara parsial terhadap variabel terikat.

\section{HASIL PENELITIAN DAN PEMBAHASAN}

\section{Hasil Penelitian}

Uji asumsi klasik meliputi uji normalitas, multikolinieritas, heterokedastisitas dan linieritas.

\section{Uji Normalitas}

Salah satu cara termudah untuk melihat normalitas adalah melihat normal probability plot yang membandingkan distribusi kumulatif dari data sesungguhnya denga distribusi kumulatif dari dstribusi normal. Distribusi normal akan membentuk suatu garis lurus diagonal dan ploting data akan dibandingkan dengan garis normal. Jika distribusi data adalah normal maka garis yang menggambarkan data sesungguhnya akan mengikuti garis diagonalnya.

2. Uji Multikolinieritas

Multikolinieritas adalah dengan melihat nilai tolerance dan nilai VIF (Variance Inflaction Factor) yang diperolehnya. Jika nilai tolerance yang diperoleh kurang dari 1dan VIF antara 1 dan 2 maka dapat dikatakan bahwa persamaan suatu model penelitian tidak menunjukkan gejala mulitikolinieritas. Nilai VIF pada variabel keyakinan diri (X1) dan pengetahuan awal (X2) diperoleh nilai sebesar 1,035 (lebih dari angka 1 dan kurang dari angka 2) maka dapat dikatakan bahwa antara variabel bebas tidak terjadi multikolinieritas. 3. Uji heterokedastisitas

Model yang baik adalah yang homokedastisitas atau tidak terjadi heterokedastisitas. Salah satu cara untuk menditeksi ada tidaknya heterokedastisitas pada suatu model persamaan regresi adalah dengan mengkorelasikan variabel bebas dengan residualnya. Dalam hal ini metode korelasi yang dipergunakan adalah korelasi rank spearman, apabila $\mathrm{p}>$ 0,05 maka tidak terjadi heterokedastisitas atau sebaliknya. Hasil uji heteroskedastisitas di atas menunjukkan bahwa nilai signifikan yang dihasilkan melebihi alpha $(\alpha)$ yang ditentukan yaitu 5\% maka dapat dikatakan bahwa antara variabel bebas dengan residual tidak 
terjadi heteroskedastisitas.

4. Uji Linieritas

Hasil uji linieritas untuk variabel keyakinan diri menunjukkan bahwa nilai uji F Deviation from linearity adalah sebesar 0,569 dengan nilai signifikan lebih dari 5\% yaitu sebesar 0,956 hal ini berarti hubungan antara keyakinan diri (X1) dengan minat belajar (Y) adalah linier. Hasil uji linieritas untuk variabel pengetahuan awal menunjukkan bahwa nilai uji $\mathrm{F}$ Deviation from linearity adalah sebesar 0,831 dengan nilai signifikan lebih dari 5\% yaitu sebesar 0,737 hal ini berarti hubungan antara pengetahuan awal (X2) dengan minat belajar $(\mathrm{Y})$ adalah linier.

Persamaan regresi, $\mathrm{Y}=46,498+1,254 \mathrm{X} 1+0,197 \mathrm{X} 2$

Dari persamaan regresi di atas menjelaskan bahwa :

a. Konstanta (a) yang dihasilkan sebesar 46,498 hal ini menunjukkan bahwa besarnya minat belajar adalah 46,498 jika variabel keyakinan diri dan pengetahuan awal adalah nol atau konstan.

b. Koefisien regresi pada variabel keyakinan diri adalah positif yaitu sebesar 1,254 artinya jika keyakinan diri naik satu satuan maka minat belajar akan naik sebesar 1,254 satuan dengan asumsi variabel pengetahuan awal adalah konstan.

c. Koefisien regresi pada variabel pengetahuan awal adalah positif yaitu sebesar 0,197 artinya jika pengetahuan awal naik satu satuan maka minat belajar akan naik sebesar 0,197 satuan dengan asumsi variabel keyakinan diri adalah konstan.

Uji F dan Nilai Koefisien Determinasi

Uji F digunakan untuk mengetahui pengaruh keyakinan diri danpengetahuan awal secara simultan terhadap minat belajar akuntansi. Adapun hasil uji $\mathrm{F}$ adalah sebagai berikut:

Tabel 1. Hasil Uji F

ANOVA

\begin{tabular}{|ll|c|r|r|r|r|}
\hline Model & & $\begin{array}{c}\text { Sum of } \\
\text { Squares }\end{array}$ & df & Mean Square & F & Sig. \\
\hline 1 & Regression & 11218.504 & 2 & 5609.252 & 58.047 & $.000^{\circ}$ \\
& Residual & 16814.004 & 174 & 96.632 & & \\
& Total & 28032.508 & 176 & & & \\
\hline
\end{tabular}

a. Predictors: (Constant), pengetahuan awal (X2), keyakinan diri (X1)

b. Dependent Variable: minat $(Y)$

Sumber : Data Diolah Peneliti

Tabel tersebut menjelaskan nilai Fhitung $=58,047$ dengan nilai signifikansi $p=0,000$ lebih kecil dari 5\% sehingga dapat disimpulkan bahwa keyakinan diri dan pengetahuan awal secara bersama-sama. Koefisien korelasi sebesar 0,633 menunjukkan bahwa minat belajar dipengaruhi oleh keyakinan diri dan pengetahuan awal sebesar 39,53\% sedangkan $60,47 \%$ dipengaruhi oleh faktor-faktor lain selain variabel keyakinan diri dan pengetahuan awal.

Uji t dan Nilai r2parsial

Uji t digunakan untuk mengetahui pengaruh keyakinan diri dan pengetahuan awal secara 
parsial terhadap minat belajar. Adapun hasil uji t adalah sebagai berikut:

Tabel 2 Hasil Uji t

\begin{tabular}{|l|c|c|c|c|}
\hline \multicolumn{1}{|c|}{ Variabel } & t-hitung & Sig & r parsial & $\mathrm{r}^{2}$ parsial \\
\hline Keyakinan diri & 9,708 & 0,000 & 0,593 & 0,3516 \\
Pengetahuan awal & 2,818 & 0,005 & 0,209 & 0,0437 \\
\hline
\end{tabular}

Sumber : Data Diolah Peneliti

Penjelasan tabel 2 di atas adalah :

a. Nilai t-hitung pada variabel keyakinan diri (X1) sebesar 9,708 dengan tingkat signifikan kurang dari 5\% yaitu 0,000. Hal ini berarti keyakinan diri (X1) secara parsial berpengaruh signifikan terhadap minat belajar (Y). Besarnya pengaruh keyakinan diri (X1) terhadap minat belajar (Y) adalah 35,16\%.

b. Nilai t-hitung pada variabel pengetahuan awal (X2) sebesar 2,818 dengan tingkat signifikan kurang dari 5\% yaitu 0,005 . Hal ini berarti pengetahuan awal (X2) secara parsial berpengaruh signifikan terhadap minat belajar (Y). Besarnya pengaruh pengetahuan awal (X2) terhadap minat belajar (Y) adalah 4,37\%.

\section{Pembahasan}

1. Pengaruh Pengetahuan Awal Terhadap Minat Belajar.

Secara teori keyakinan diri dapat mempengaruhi minat, hal ini sesuai dengan pendapat Bandura (2012:7) yang menyatakan bahwa orang dengan keyakinan yang kuat akan memiliki kemampuan diantaranya (1) menganggap tugas yang sulit sebagai tantangan yang harus dikuasai (bukan ancaman yang harus dihindari), (2) menumbuhkan ketertarikan, (3) menetapkan tujuan yang menantang dan menjaga komitmen terhadap tujuan tersebut dan (4) memiliki usaha yang tinggi, sehingga mereka berfikir secara strategi, mengaitkan kegagalan dengan usaha yang cukup dan cepat bangkit setelah mengalami kegagalan.

Hasil penelitian ini sependapat dengan uraian tersebut di atas, terlihat dari hasil uji t yaitu nilai t-hitung yang dihasilkan sebesar 9,708 dengan tingkat signifikan kurang dari $5 \%$ yaitu 0,000 . Hal ini berarti keyakinan diri (X1) secara parsial berpengaruh signifikan terhadap minat belajar (Y). Sedangkan besarnya pengaruh keyakinan diri (X1) terhadap minat belajar (Y) adalah 35,16\%. Pengaruh keyakinan diri (X1) terhadap minat belajar (Y) sangat besar dikarenakan siswa SMA Negeri yang ada di kota Mojokerto memiliki keyakinan diri yang cukup tinggi terbukti dengan terbiasanya menyelesaikan tugas sekolah dan soal-soal materi akuntansi yang bobotnya sulit sekalipun, memiliki keyakinan yang cukup tinggi tidak terbatas pada situasi yang spesifik saja pada mata pelajaran ekonomi materi akuntansi tetapi juga untuk mata pelajaran yang lainnya dan memiliki ketahanan atau kemantapan dalam mengerjakan tugas-tugas mata pelajaran ekonomi materi akuntansi. Terutama untuk SMA Negeri 2 Kota Mojokerto yang memiliki keyakinan lebih tinggi dibandingkan SMA Negeri 1 Kota Mojokerto dan SMA Negeri 3 Kota Mojokerto mempunyai keyakinan diri yang cukup dibuktikan dari tabulasi jawaban responden. Sehingga siswa kelas XII IPS SMA Negeri yang berada di kota Mojokerto memiliki keyakinan diri yang cukup tinggi sehingga minat belajar terhadap mata pelajaran akuntansi pun juga cenderung tinggi. Hal ini didukung oleh teori Bandura (2012:1) keyakinan diri akan mempengaruhi: 1) Tindakan, 2) Upaya, 3) Ketekunan dalam menghadapi rintangan 
dan kegagalan, 4) Ketahanan terhadap kesulitan, 5) Pola pikir, 6) Stres dan depresi pada situasi berat, 7) Menyadari tingkat prestasi.

Hasil penelitian ini mendukung hasil penelitian Zimmerman, B.J., (2000:8) yang mengatakan bahwa keyakinan diri sangat penting sebagai prediksi paling efektif pada motivasi siswa dan pembelajaran. Hasil penelitian ini juga mendukung hasil penelitian Linda H. Meyer (2005:225) menyatakan bahwa keyakinan diri atau self efficacy sangat mendukung lingkungan belajar. Hasil penelitian ini juga mendukung hasil penelitian Tandelilin (2005:253) yang menyatakan bahwa keyakinan diri (self efficacy) mahasiswa berhubungan positif dengan prestasi mahasiswa.

\section{Pengaruh Pengetahuan Awal Terhadap Minat Belajar.}

Secara teori pengetahuan awal dapat mempengaruhi minat, seperti yang dikatakan Renninger (dalam Schunk, 2012:321) minat memberikan nilai yang tinggi untuk sebuah aktivitas, jika individu hanya memiliki sedikit pengetahuan tentang sebuah aktivitas atau topik, sulit baginya menilai minatnya terhadap aktivitas atau topik tersebut. Individu biasanya memiliki lebih banyak pengetahuan tentang aktivitas yang sangat diminatinya dan yang akan ia berikan nilai tinggi. Oleh karena itu jika individu memberikan nilai tinggi untuk sebuah aktivitas, namun berlevel pengetahuan rendah tentang aktivitas tersebut maka bukanlah minat melainkan ketertarikkan.

Hasil penelitian ini sependapat dengan uraian tersebut di atas, terlihat dari hasil uji t yaitu nilai t-hitung yang dihasilkan sebesar 2,818 dengan tingkat signifikan kurang dari $5 \%$ yaitu 0,005 . Hal ini berarti pengetahuan awal (X2) secara parsial berpengaruh signifikan terhadap minat belajar (Y). Sedangkan besarnya pengaruh pengetahuan awal (X2) terhadap minat belajar (Y) adalah 4,37\%. Pengaruh pengetahuan awal (X2) terhadap minat belajar (Y) jauh lebih kecil dibandingkan dengan keyakinan diri karena diketahui dari masing-masih sekolah khususnya SMA Negeri 1 Kota Mojokerto yang rata-rata nilai ulangan harian masih dibawah KKM, untuk SMA Negeri 3 Kota Mojokerto pas sesuai KKM dan hanya SMA Negeri 2 Kota Mojokerto yang nilai rata-rata ulangan hariannya berada di atas KKM. Sehingga secara parsial pengetahuan awal (X2) sangat kecil pengaruhnya terhadap minat belajar siswa (Y) pada mata pelajaran ekonomi materi akuntansi. Hal ini didukung oleh teori Arend (dalam Rahmatan dan Liliasari, 2012:92) tentang pentingnya pengetahuan awal adalah untuk membantu siswa membangun jembatan antara pengetahuan baru dengan pengetahuan yang telah dimiliki. Hasil penelitian ini juga dibuktikan dari tabulasi jawaban responden yaitu siswa kelas XII IPS SMA Negeri yang berada di kota Mojokerto memiliki nilai rata-rata ulangan harian yang cenderung tinggi, hal ini menunjukkan bahwa minat belajar mereka terhadap mata pelajaran akuntansi cenderung tinggi.

Hasil penelitian ini mendukung hasil penelitian Ross A. Thomson (2004:778) mengatakan diluar kemampuan umum, kemampuan sebelumnya sangat memfasilitasi belajar siswa dalam pengantar psikologi. Hasil penelitian ini juga mendukung hasil penelitian Prastiti (2007:199) mengatakan bahwa pengetahuan awal mampu meningkatkan kemampuan komunikasi dan pemahaman matematika siswa secara signifikan. Hasil penelitian ini juga mendukung hasil penelitian Samsul Bahri dan Evi Apriana (2008:58) mengatakan keberhasilan siswa dalam mencapai suatu tahap hasil belajar memungkinkan untuk belajar lebih lancar dalam mencapai tahap selanjutnya.

\section{Pengaruh Keyakinan Diri dan Pengetahuan Awal Terhadap Minat Belajar.}


Secara parsial keyakinan diri berpengaruh signifikan terhadap minat belajar dan pengetahuan awal berpengaruh signifikan terhadap minat belajar. Begitu juga dengan secara simultan, keyakinan diri dan pengetahuan awal berpengaruh signifikan terhadap minat belajar. Hal ini dapat dilihat dari nilai Fhitung yang dihasilkan yaitu 58,047 dengan nilai signifikansi $\mathrm{p}=0,000$ lebih kecil dari 5\%. Sedangkan besarnya pengaruh keyakinan diri dan pengetahuan awal terhadap minat belajar sebesar $40 \%$ dan sisanya $60 \%$ dipengaruhi oleh faktor-faktor lain selain variabel keyakinan diri dan pengetahuan awal.

Dalam hasil penelitian ini menunjukkan bahwa keyakinan diri yang dimiliki SMA Negeri 1 Kota Mojokerto, SMA Negeri 2 Kota Mojokerto dan SMA Negeri 3 Kota Mojokerto berpengaruh besar terhadap minat belajar yaitu sebesar 35,16\% hal ini disebabkan keyakinan diri yang dimiliki SMA Negeri 1 Kota Mojokerto dalam kategori cukup tinggi, keyakinan diri yang dimiliki SMA Negeri 2 Mojokerto termasuk kategori tinggi dan keyakinan diri yang dimiliki SMA Negeri 3 masuk kategori cukup tinggi sehingga berpengaruh tinggi juga terhadap minat belajar. Sedangkan pengetahuan awal yang dimiliki SMA Negeri 1 Kota Mojokerto, SMA Negeri 2 Kota Mojokerto dan SMA Negeri 3 Kota Mojokerto berpengaruh sangat kecil terhadap minat belajar yatiu sebesar 4,37\% hal ini disebabkan dari rata-rata nilai ulangan harian yang mendekati KKM sehingga pengetahuan awal sangat berpengaruh sangat kecil terhadap minat belajar materi akuntansi di kelas XII. Hal ini didukung oleh teori Goleman (2000:46) melalui penelitiannya mengatakan bahwa kecerdasan emosi menyumbang $80 \%$ dari factor penentu kesuksesan seseorang, sedangkan 20\% yang lain ditentukan oleh IQ (Intelligence Quetient).

\section{KESIMPULAN}

Dari pembahasan yang telah diuraikan, maka dapat ditarik kesimpulan sebagai berikut:

1. SMA Negeri 2 Kota Mojokerto memiliki keyakinan diri yang tinggi dilihat dari dimensi magnitude, generality, strength. SMA Negeri 3 Kota Mojokerto memiliki keyakinan diri dalam kategori cukup dilihat dari dimensi magnitude, generality, strength. SMA Negeri 1 Kota Mojokerto memiliki keyakinan diri dalam kategori cukup dilihat dari dimensi magnitude, generality, strength. Jadi dapat disimpulkan ada pengaruh keyakinan diri (self efficacy) terhadap minat belajar materi akuntansi kelas XII tingkat SMA Negeri di Kota Mojokerto.

2. SMA Negeri 2 Kota Mojokerto memiliki pengetahuan awal berupa rata-rata nilai ulangan harian di atas KKM dengan mean sebesar 77,37, SMA Negeri 3 Kota Mojokerto memiliki pengetahuan awal berupa nilai rata-rata ulangan harian sesuai KKM dengan mean sebesar 75,46 dan SMA Negeri 1 Kota Mojokerto memiliki pengetahuan awal berupa rata-rata nilai ulangan harian di bawah KKM dengan mean sebesar 74,32. Ada pengaruh pengetahuan awal (prior knowledge) terhadap minat belajar akuntansi kelas XII IPS tingkat SMA Negeri di Kota Mojokerto.

3. Ada pengaruh keyakinan diri (self efficacy) dan pengetahuan awal (prior knowledge) terhadap minat belajar akuntansi kelas XII IPS tingkat SMA Negeri di Kota Mojokerto, meskipun pengaruh keyakinan diri lebih dominan dibandingkan dengan pengetahuan awal, karena keyakinan diri yang dimiliki oleh SMA Negeri yang ada di Mojokerto dalam kategori yang cukup tinggi sedangkan pengetahuan awal hanya sebatas KKM yang ditetapkan. 
Saran-saran yang dapat diberikan sebagai tindak lanjut dari hasil penelitian adalah sebagai berikut:

1. Keyakinan diri (Self efficacy) sangatlah besar pengaruhnya terhadap pembentukan minat belajar siswa. Untuk SMA Negeri 1 Kota Mojokerto dan SMA Negeri 3 Kota Mojokerto hendaknya menumbuh kembangkan keyakinan diri siswa karena dengan keyakinan diri dapat membangun potensi siswa sehingga memberikan dampak yang besar untuk membentuk karakter siswa dalam meraih kesuksesan. Sedangkan untuk SMA Negeri 2 Kota Mojokerto perlu dipertahankan dan ditingkatkan karena meskipun sudah memiliki keyakinan diri yang tinggi jika tidak dibina akan menurun dan mempengaruhi kesuksesan yang sudah didapat.

2. Pengetahuan awal sangatlah penting keberadaannya, untuk meningkatkan minat belajar, sebagai pendidik membekali siswa pengetahuan sesuai dengan kompetensi yang telah ditentukan. Untuk SMA Negeri 1 Kota Mojokerto diharapkan dapat mencapai nilai rata-rata minimal sesuai KKM untuk melanjutkan materi berikutnya, untuk SMA Negeri 2 Kota Mojokerto sudah mencapai nilai rata-rata diatas KKM diharapkan dapat dipertahankan bahkan bisa ditingkatkan lagi dan untuk SMA Negeri 3 diharapkan dapat meningkatkan nilai rata-rata diatas KKM karena meskipun sudah mencapai KKM tetapi belum melebihi dari nilai KKM sehingga bekal pengetahuan awal siswa untuk belajar materi berikutnya masih kurang.

3. Hasil penelitian ini diharapkan dapat menjadi bahan masukan bagi sekolah-sekolah lain, meskipun mungkin tidak sepenuhnya akurat bila diterapkan karena situasi dan kondisi sekolah yang berbeda.

4. Bagi peneliti berikutnya diharapkan dapat mengembangkan penelitian yang berkaitan dengan peningkatan minat belajar siswa melalui variabel keyakinan diri dan pengetahuan awal maupun melalui variabel-variabel lain yang mempengaruhi misalnya gaya belajar siswa, motivasi, kecerdasan siswa dan model pembelajaran.

\section{DAFTAR RUJUKAN}

Amalia, Rika Indah. 2008. "Pengaruh Self Efficacy Beliefs terhadap Prestasi Akademik Siswa SMA Kelas XI Jurusan IPS”.Jurnal Fakultas Psikologi Universitas Gunadarma.

Bandura, Albert. 2012. Self Efficacy The Exercise of Control. (online). http://www.des. emory.edu/mfp/effbook5.html. diakses tanggal 27 Agustus 2012.

Chasanah, Nur. 2008. “Analisis Pengaruh Empowerment Self Efficacy dan Budaya Organisasi Terhadap Kepuasan Kerja dalam Meningkatkan Kinerja Karyawan” Tesis. Semarang.

Goleman, Daniel. 200o. Kecerdasa Emosi: Mengapa Emotional Intelligence lebih Tinggi Daripada IQ, alih Bahasa: T. Hermany. Jakarta: PT Gramedia Pustaka Utama.

Hajar, Ibnu. 1999. Dasar-dasar Metodologi Penelitian Kwantitatif dalam Pendidikan. Jakarta: PT Raja Grafindo Pustaka.

Hariwijaya, Mohammad. 2008. Cara Mudah Menyusun Proposal Skripsi, Tesis dan Disertasi. Jogyakarta: Pararaton.

Harry B. Santoso, Tunggul Fardiaz dan Zainal A Hasibuan. 2012. "Implementasi Fitur Perekomendasian Bahan Ajar Berdasarkan Prior Knowledge pada Student Centered E- 
Learning Environment”. Seminar Nasional Aplikasi Tehnologi Informasi. 20 Juni 2009. Yogyakarta.

Kurikulum KTSP. Standar Kompetensi Mata Pelajaran Ekonomi SMA dan MA. Jakarta: Depdiknas.

Linda H. Meyer and Carol S. Sternberger. 2005. Jurnal World Academy of Science, Engineering and Technology 8. 2005. Pp 225-229.

Nur, Mohamad. 2011. Strategi-strategi Belajar. Surabaya: Pusat Sains dan Matematika Sekolah UNESA.

Prastiti, Tri Dyah.” Pengaruh Pendekatan Pembelajaran RME dan Pengetahuan Awal Terhadap Kemampuan Komunikasi dan Pemahaman Matematika Siswa SMP Kelas VII". Didaktika, Vol.2 No.1 Maret 2007:199-215

Rahmatan dan Liliasari. 2012. "Pengetahuan Awal Calon Guru Biologi Tentang Konsep Katabolisme Karbohidrat (Respirasi Seluler)". Jurnal Pendidikan IPA Indonesia. Volume 1. 2012. Pp 91-97.

Ross A. Thomson and Byron L. Zamboanga. 2004."Academic Aptitude and Prior Knowledge as Predictors of Student Achievement in Introduction to Psychology". Journal of Educational Psychology. Volume 96. Nomor 4. 2004. Pp 778-784.

Samsul Bahri dan Evi Apriana. 2008."Peran Pengetahuan Awal, Strategi Kognitif dan Metakognitif terhadap Pencapaian Hasil Belajar IPA”. Jurnal Pendidikan Serambi Ilmu. Volume 6. Nomor 1. 2008. Pp 58-64.

Santrock, John W. 2009. Psikologi Pendidikan Educational Psychology. Jakarta: Salemba Humanika.

Schunk, Pintrich, Meece. 2012. Motivasi dalam Pendidikan, Teori, Penelitian dan Aplikasi. Jakarta: Indeks.

Setiadi, Riswanda. 2007. "Efikasi Diri dan Kinerja Guru Serta Hasil Belajar Literasi Siswa". Makalah Disampaikan dalam Forum Ilmiah Fakultas Pendidikan Bahasa dan Seni Universitas Pendidikan Indonesia. 22 November 2007. Bandung.

Slameto. 2010. Belajar dan Faktor-faktor yang Mempengaruhinya. Jakarta: Rineka Cipta. Sugiono. 2010. Statistika untuk Penelitian. Bandung: Alfabeta

Tandelilin, Elsye. 2005. "Kompetensi Dosen, Keyakinan Diri (Self Efficacy) dan Motivasi Mahasiswa: Penagruhnya terhadap Prestasi Mahasiswa (Student Achievement) Fakultas Ekonomi Universitas Surabaya". Jurnal Aplikasi Manajemen. Volume 3. Nomor 3. Desember 2005. Pp 253-259. 